\title{
PROSES PEMBELAJARAN SISWA SEKOLAH DASAR DI MI NURUL HIKMAH
}

\author{
Siti Nurfaizah \& Putri Oktavia \\ Universitas Muhammadiyah Tangerang \\ siti.nurfaizah@umt.ac.id
}

\begin{abstract}
The study was conducted to analyze the relationship between the learning environment and the learning process in an effort to improve student achievement in school, analysis using qualitative methods. Research conducted on madrasa ibtidaiyah teachers NURUL HIKMAH. From this study it can be seen that the learning environment has a positive relationship with student learning achievement, as well as the learning process that has a positive and significant relationship to student learning achievement, this shows that good student achievement can be done in an effort to improve the quality of the learning environment at school and the existence of a quality learning process, thus efforts to improve student achievement can be done by improving and improving the quality of the learning process as well as an increase in the quality of teaching staff in schools so that they are more professional in carrying out their duties and responsibilities as a teacher.
\end{abstract}

Keywords: Learning, Learning Achievement

\begin{abstract}
Abstrak : Penelitian di lakukan untuk menganalisis hubungan lingkungan belajar dan proses pembelajaran dalam upaya peningkatan prestasi siswa di sekolah, analisis menggunakan metode kualitatif. Penelitian di lakukan terhadap guru-guru madrasah ibtidaiyah NURUL HIKMAH. Dari penelitian ini dapat di ketahui bahwa lingkungan belajar memiliki hubungan yang positif terhadap prestasi belajar siswa, begitu pula dengan proses pembelajaran yang memiliki hubungan positif dan signifikan terhadap prestasi belajar siswa, hal ini menunjukan bahwa pencapaian prestasi belajar siswa yang baik dapat di lakukan dalam upaya peningkatan kualitas lingkungan belajar di sekolah serta adanya proses pembelajaran yang berkualitas, dengan demikian maka upaya dalam peningkatan prestasi belajar siswa dapat di lakukan dengan perbaikan dan peningkatan kualitas proses pembelajaran serta adanya peningkatan kualitas tenaga pendidik di sekolah sehingga lebih profesional dalam menjalankan tugas dan tanggung jawab sebagai seorang tenaga pendidik.
\end{abstract}

Kata Kunci : Pembelajaran, Prestasi Belajar

\section{PENDAHULUAN}

Proses pendidikan adalah attivitas yang sangat panjang dan penuh dengan perencanaan yang matang dengan tujuan yang seperti tertuang dalam uandangundang republik indonesia nomor 20 tahun 2003 tentang sistem pendidikan nasional yaitu: pendidikan nasional berfungsi mengembangkan kemampuan dan membentuk

As-Sabiqun : Jurnal Pendidikan Islam Anak Usia Dini

Volume 2, Nomor 1, Maret 2020; 43-48

https://ejournal.stitpn.ac.id/index.php/assabiqun 
watak serta peradaban bangsa yang bermartabat dalam rangka mencerdaskan kehidupan bangsa, bertujuan untuk mengembangkan potensi peserta didik agar menjadi manusia yang beriman dan bertaqwa kepada tuhan yang maha esa, berakhlak mulia, sehat, berilmu, cakap, kreatif, mandiri dan menjadi warga negara yang demokratis serta bertanggung jawab.

Sebagai suatu proses, belajar hampir selalu mendapat tempat yang luas dalam berbagai disiplin ilmu yang berkaitan dengan upaya pendidikan. Perubahan dan kemampuan untuk berubah merupakan

batasan dan makna yang terkandung dalam belajar. Selain itu dengan kemampuan berubah melalui belajar itu, manusia secara bebas dapat mengeksplorasi,memilih,dan menetapkan keputusan -keputusan penting dalam kehidupan nya.

Setiap siswa pada prinsipnya tertentu berhak memperoleh peluang untuk mencapai kinerja akademik ( academic performance) yang memuaskan.namun dari kenyataan sehari-hari tampak jelas bahwa siswa itu memiliki perbedaan dalam hal kemampuan intelektual,kemampuan fisik,latar belakang keluarga,kebiasaan dan pendekatan belajar yang terkadang sangat mencolok antara siswa dengan siswa lain nya.

Oleh karena itu, hal tersebut dapat di atasi dengan memperhatikan faktorfaktor yang dapat menghambat proses dan hasil belajar siswa serta bagaimana cara atau strategi yang tepat dalam mengoptimalkan hasil belajar,sehingga dapat mengurangi masalah atau kesulitan pada siswa itu sendiri.

\section{METODE PENELITIAN}

\section{Jenis Penelitian}

Jenis penelitian ini merupakan jenis penelitian deskriptif kualitatif, karena dalam penelitian ini mendeskripsikan keadaan yang terjadi pada pada saat sekarang secara sistematis dan faktual dengan tujuan untuk menghasilkan data deskripsi berupa kata kata tertulis atau lisan dari orang-orang atau prilaku yang di amati penelitian ini di lakukan di MI NURUL HIKMAH kota tangerang. 


\section{Tempat dan Waktu Penelitian}

Observasi ini di lakukan pada hari sabtu yang bertepatan pada tanggal 16 november 2019 dan dalam penelitian observasi ini di lakukan di sekolah Mi nurul hikmah

\section{Subjek Penelitian}

Subjek di dalam penelitian ini adalah guru

a.) Biodata siswa

Berikut ini adalah biodata salah satu siswa yang di kelas nya memiliki masalah dalam belajar di sekolah.

Nama: Naufal Yaafi Abdul Rafiq

Kelas: 4

Sekolah :Mi nurul hikmah

Tempat tanggal lahir : Tangerang,22 september 2008

Nama orang tua

Ayah : Abdul Rafiq

Ibu : Nurchasanah

Pekerjaan orang tua

Ayah: Pegawai swasta

Ibu: IRT( ibu rumah tangga)

b). Masalah siswa

1. jarang mengerjakan tugas

2. kurang memperhatikan guru ketika sedang di jelaskan.

3. jarang masuk kelas.

\section{Desain dan prosedur penelitian}

Penelitian yang di gunakan oleh penulis adalah observasi dan wawancara.

1. Observasi

Teknik pengumpulan data,di mana peneliti melakukan pengamatan langsung ke objek penelitian untuk melihat dari dekat kegiatan yang di lakukan. Dalam metode observasi ini,penulis melakukan pengamatan dan 
mencatat hal-hal penting yang di jadikan bahan observasi. Tentunya dengan situasi dan kondisi yang sesuai fakta tanpa ada nya memanipulasi.

Keterangan

a. Mempersiapkan surat izin

b. Menyiapkan biodata siswa

c. Mewawancarai siswa,dan guru untuk analisis data

2. Wawancara

Teknik pengumpulan data dengan jalan tanya jawab sepihak yang dllakukan secara sistematis dan berlandaskan kepada tujuan penelitian.

Inilah berikut wawancara saya dengan beberapa anak di sekolah tersebut.

a. Lebih suka mengerjakan tugas di rumah atau di sekolah ? alasan nya? Siswa laki-laki ini menjawab di rumah, alasan nya supaya tidak pada nyontek dan lebih konsentrasi pada tugas.

b. Apa tujuan mereka ke sekolah? Beberapa siswa yang kami tanyai menjawab bahwa tujuan mereka adalah ingin benar-benar belajar untuk meraih cita-cita mereka.

c. Menurut kamu apakah sarapan sebelum berangkat sekolah itu penting atau tidak ? alasannya? Mereka menjawab sangat penting karna kalau sudah makan maka akan lebih konsentrasi jika belajar, dan lebih masuk ke dalam otak.

d. Bagaimana sistem belajar kamu ketika menghadapi ujian sekolah ? Siswa tersebut menjawab bahwa kalau di rumah belajar di baca dan di hafal serta di pahami makna nya agar tidak cepat lupa.

e. Misal nya ada teman kamu yang belajar pada saat jam istirahat, apakah kamu ikut belajar juga atau tidak? Alasan nya ? Mereka menjawab tidak, karena itu jam istirahat yang seharusnya di pakai dengan sebaik-baik mungkin.

f. Seneng ga sih di beri tugas oleh guru? Mereka menjawab senang karena bisa mengasah kemampuan dari materi yang sudah di pelajari. 
g. Apa sih cita-cita kalian? ada yang menjawab menjadi polisi karena supaya bisa menjaga orang-orang di sekitar, ada juga yang menjawab ingin menjadi guru karena bisa mengamalkan ilmu nya sampai akhirat nanti.

\section{HASIL PENELITIAN DAN PEMBAHASAN}

Pada penelitian ini saya mendapatkan kesempatan langsung untuk melihat proses belajar mengajar didalam kelas nya. Dengan hal ini maka akan memperkuat data yang saya butuhkan. Pada hari itu materi yang di ajarkan mengenai seni budaya keterampilan (SBK), mereka biasa nya selalu menggambar sesuai apa yang mereka pikirkan atau imajinasi kan. Dari dalam kelas saya dan temen saya yang bertugas memantau bagaimana perkembangan anak itu,mereka ada yang benar-benar teliti dalam menggambar ada juga yang semau nya saja dalam menggambar. Dari situ saya sudah mulai paham bagaimana karakter anak dari segi dia berfikir dalam mengimajinasikan pikiran nya dengan mengambar apa yang dia pikirkan.

Demikian beberapa gambaran observasi yang penulis lakukan terhadap pelaku yang mana untuk mengetahui segala pola tingkah laku yang dia lakukan selama proses belajar mengajar di sekolah selama beberapa jam.

Belajar adalah kegiatan yang berproses dan merupakan unsur yang sangat fundamental dalam meyelenggarakan setiap jenis dan jenjang pendidikan. Oleh karna nya, pemahaman yang benar mengenai arti belajar dengan segala aspek, bentuk,dan manifestasi nya mutlak di perlukan oleh para pendidik khusus nya para guru.

Pembelajaran merupakan proses kegiatan belajar mengajar yang juga berperan dalam menentukan keberhasilan belajar siswa. Dari proses pembelajaran itu akan terjadi sebuah kegiatan timbal balik antara guru dengan siswa untuk menuju tujuan yang lebih baik. Oleh karena itu, proses pembelajaran musik yang tepat di ekstrakulikuler band sangat di butuhkan dalam kegiatan berkesenian untuk menghasilkan sebuah karya musik melalui aransemen yang pada akhirnya lagu tersebut terkesan baru dan siswa mampu untuk membawakan musik dengan baik. 
Untuk melakukan sebuah proses pembelajaran, terlebih dahulu harus di pahami pengertian dari kata pembelajaran.

Proses belajar mengajar merupakan suatu proses yang mengandung serangkaian perbuatan guru dan siswa atas dasar hubungan timbal balik yang berlangsung dalam situasi edukatif untuk mencapai tujuan tertentu. Proses pembelajaran merupakan suatu kegiatan interaksi anatara guru dan siswa di mana akan di akhiri dengan proses evaluasi hasil belajar. Dalam proses harus d butuhkan seorang guru sebagai pemberi ilmu pengetahuan.

\section{KESIMPULAN}

Belajar adalah suatu proses dari perkembangan hidup manusia dan melakukan perubahan-perubahan kualitatif individu sehingga dapat mengarah kearah tingkah laku yang lebih baik. Namun ada beberapa faktor yang dapat mengakibatkan anak memiliki masalah atau kesulitan dalam mencapai prestasi belajar serta tingkah laku nya. Untuk itu peran orang tua dan guru sangatlah penting dan berpengaruh dalam proses dan hasil belajar siswa.

\section{DAFTAR PUSTAKA}

Dimyati dan mudjiono, 2002. belajar dan pembelajaran, jakarta : Rineka Cipta.

Djaali, 2012. Psikologi pendidikan. Jakarta: PT Bumi Aksara.

Magdalena ina, 2019. psikologi pendidikan, yogyakarta: Samudra Biru.

Muhibin Syah, 2011. Psikologi Pendidikan dengan pendekatan baru. Bandung: PT

Remaja rosdakarya. 